\title{
The isoepoxydon dehydrogenase gene of patulin biosynthesis in cultures and secondary metabolites as candidate PCR inhibitors
}

\author{
R. Russell M. PATERSON \\ Micoteca da Universidade do Minho (MUM), Centro de Engenharia Biológica, Campus de Gualtar, 4710-057 Braga, Portugal. \\ E-mail: russell.paterson@deb.uminho.pt
}

Received 20 March 2004; accepted 30 August 2004.

The European Union (EU) has introduced statutory limits for patulin in fruit products. Species definitions need to be unambiguous for this capability, especially to determine 'weak spots' in food, drink and feed production. Fungi were analysed for the isoepoxydon dehydrogenase (IDH) gene of the patulin metabolic pathway to indicate potential patulin production. In several cases inhibition of PCR product formation was indicated. Dilution as a means of overcoming PCR inhibition and to determine optimal concentrations was assessed and the ramifications for nucleic acid analysis in general are highlighted. The inhibitors may be secondary metabolites. However, inhibition was not involved obviously for Penicillium brevicompactum. The gene was detected frequently from Aspergillus section Clavati and Penicillium subgenus Penicillium species. Some strains within certain species were negative for the gene. Detection of the gene product in Byssochlamys is reported.

\section{INTRODUCTION}

Mycotoxins contaminate foodstuff and are produced by many fungi. Their quantity is unknown; thousands of toxic metabolites could be involved. However, at least six principal mycotoxins, which are secondary metabolites (low molecular weight compounds unnecessary for growth) have been described (CAST 2003).

The mycotoxin patulin (Fig. 1) has assumed increased importance: European Union (EU) regulations on maximum concentrations in fruit products have been agreed recently (Byrne 2004). Many non-EU countries have recommended highest or action levels. The metabolite is associated with Penicillium expansum, the causal agent of blue rot of apples. Apple juice contamination is the problem most recognised. However, it is produced by other fungi and in other food and feed; it is the most common mycotoxin in silage and has been detected frequently in malt. Strains of the ubiquitous $P$. brevicompactum can produce the compound (Paterson et al. 2003), increasing the risk of patulin exposure. It was not detected previously (Paterson \& Kemmelmeier (1989). Peterson (2004) demonstrated that strains with a similar conidiophore (Paterson, Venâncio \& Lima 2004) cluster into three clades, and it is desirable to determine patulin-producing potential within them. In addition, patulin can be produced by $P$. roquefort $i$ which is used to produce blue cheese, although it may be degraded in reactions with sulphur-containing proteins. It is important that fungi used in the manufacturing of organic acids, enzymes, and pharmaceuticals do not produce patulin (Paterson, Venâncio \& Lima 2004).

Patulin may be more problematic than other mycotoxins as it is produced by a wide range of fungi (Paterson et al. 2003, Paterson 2003), which may reflect an imperfect taxonomy (Paterson, Venâncio \& Lima 2004). P. verrucosum has been discussed as one producer in Laich, Fierro \& Martin (2002), although ochratoxin $\mathrm{A}$ is not mentioned with which the fungus is associated conventionally. Furthermore, patulin production is not considered to be a characteristic of the section Expansa to which P. expansum belongs (Frisvad et al. 2000). Definitions of patulin-producing fungi need to be unambiguous to enable the determination of 'weak spots' in commodity systems.

Elucidation of the patulin biosynthetic pathway and genetics may suggest how production might be controlled/stopped (Bhatnagar et al. 2004). Investigations of the regulation, the biosynthesis pathway and the genetics of patulin production have been undertaken as it is a model secondary metabolite, polyketide and antibiotic. Studies have focussed on P. urticae (Scott et al. 1986, Wang, Reeves \& Gaucher 1991), P. patulum (Yalpani et al. 2001) and P. griseofulvum (e.g. Nicolaisen, Frisvad \& Rossen 1997) and have 


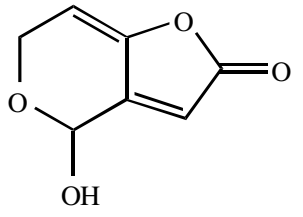

Fig. 1. Chemical structure of patulin.

specifically examined the role of the 6-methylsalicylic acid synthase gene, which is fundamental for patulin production. Concerns remain regarding duplicated work since $P$. urticae and $P$. patulum are synonyms of $P$. griseofulvum (e.g. Frisvad et al. 2000). In addition, disease resistance has been activated in tobacco by expression of the enzyme from $P$. patulum, in which $P$. griseofulvum is referred to as an anamorph (Yalpani et al. 2001).

Patulin can be considered a model mycotoxin with which generic studies can be undertaken. To date studies have examined the effects of preservation on mycotoxin production (Santos et al. 2002); manganese ions were crucial to its formation (Scott et al. 1986); it is degraded by (1) sulphur dioxide (Moss 1998), (2) sulphur containing proteins, and (3) Saccharomyces cerevisiae alcoholic fermentation (Moss 1998), although whether this applies to continuous culture requires investigation. ${ }^{1}$ All of this information needs to be considered urgently if methods for reducing patulin in commodities are to be found.

Patulin is extremely toxic, exhibits mutagenic properties, and is possibly carcinogenic. Strong antibiotic activity has been described, including activity against Mycobacterium tuberculosis. It is immunosuppressive, and ulceration, congestion, and haemorrhagic lesions can be produced. The toxicity of patulin is related to its ability to alkylate several enzymes, and inhibit translation/transcription by direct effects on DNA (www.inchem.org).

A polyketide pathway is involved in the synthesis of patulin, where the conversion of isoepoxydon to phyllostine is a unique and late step in P. griseofulvum. Isoepoxydon dehydrogenase (IDH) catalyses the reaction, and the gene responsible was sequenced by Fedeshko (1992). Environmental samples and isolated penicillia were analysed for the IDH gene (Paterson et al. 2000, 2003) and the fungi were analysed for patulin. The gene was detected in: (1) a wide range of fungi in addition to $P$. griseofulvum; and (2) twigs, soil, decayed apples, etc. The gene was detected in $P$. brevicompactum for the first time. This is of some concern as the species is ubiquitous and presents a high risk to commodities. Paterson \& Kemmelmeier (1989)

1 A vast amount of valid information regarding the chemistry, degradation and toxicology of patulin, and other mycotoxins, is provided on www.inchem.org; a considerable amount of that data is relevant to the present paper, and the potential problems of the presence of mycotoxins to nucleic acid analysis. did not detect patulin from one strain, but Varga et al. (2003) reported patulin production (and the gene) in Aspergillus longivesica.

Other taxa reported to produce patulin include: $A$. terreus, which is isolated frequently from soil and is an opportunistic pathogen of humans and animals; A. clavatus and A. giganteus which can be isolated from soil, dung and stored products (mainly cereals); $A$. clavatus which is responsible for extrinsic allergic alveolitis (malt worker's lung), and mycotoxin(s) from it were implicated in animal mycotoxicosis; Byssochlamys fulva and $B$. nivea which produce heat-resistant spores, and can contaminate canned food by surviving the heating process and may be responsible for patulin production therein; Paecilomyces variotii, a thermotolerant species, which can be isolated from decaying plants and food products; Penicillium glandicola and $P$. glandicola var. glaucoventum are coprophilic and synnematous penicillia that have similar HPLC profiles of secondary metabolites; P. griseofulvum and its var. dipodomyicola found on dry cereals and seeds, which share key morphological features as well as producing griseofulvin and cyclopiazonic acid (although other metabolites are unique); P. melinii, which is important in soil ecology and is an occasional contaminant of foods and feeds, and the ex-type strain is reported to produce patulin while some other strains do not; $P$. selandiae, which has not been described formally but was isolated as $P$. antarcticum from a different location; and $P$. antarcticum which produces patulin and belongs in sect. Furcatum, and is probably close to $P$. paxilli and related species Jens C. Frisvad, pers. comm.

PCR amplification of DNA from soil is susceptible to interference from, for example, humic acid substances. Also, humic material copurifies with DNA during extraction (Johnston \& Aust 1994). It is well known that the water-soluble fraction of humic acids over all $\mathrm{pH}$ ranges are fulvic acids. Fulvic acid is a fungal extrolite (Wang et al. 1995) produced by a widerange of fungi, including $P$. griseofulvum (Frisvad \& Thrane 1993). Also, there are compounds similar to fulvic acid which are fungal extrolites. This establishes that certain fungal metabolites may interfere with the PCR when produced, and indicates that it would be prudent to minimise the presence of secondary metabolites during nucleic acid analysis. In addition, brevianamides have been reported in 'spent' growth medium often used to produce fungal biomass for DNA extraction and PCR analysis (Paterson et al. 2004).

However, as mentioned earlier, if soil contains fungi which produce extrolites that interact with DNA, they also may cause problems. Patulin inhibits protein synthesis, transcription, translation, forms adducts with DNA and is mutagenic; lovistatin inhibits its own synthesis (Casas Lopez et al. 2004). If PCR is to be used to screen samples for patulin biosynthetic genes, it is important to establish whether extrolites can affect nucleic acid analysis in fungi (and other extrolite-producing 
plants and bacteria); www.inchem.org should be consulted to appreciate the profound effects that mycotoxins are reported to have on DNA and proteins.

Data for IDH gene analysis of numerous fungi are presented herein, and the effect of dilution to remove potential interfering substances is described. For this study the contents of freeze dried ampoules were analysed.

\section{MATERIAL AND METHODS}

Freeze dried ampoules of fungi were obtained from IMI (CABI Bioscience, Egham) for direct analysis, or for growth prior to DNA extraction. Methods of growth were as in Paterson et al. (2003). Some of the strains were chosen because they had been reported to produce patulin, and ex-type strains were used whenever possible (Table 1). The remainder were strains isolated from various apple production systems in England (Paterson et al. 2003). Controls were: a Ganoderma sp. (IMI 357185), a basidiomycete which may cause disease of oil palm; and an Aspergillus flavus (IMI 380661) strain, some of which produce aflatoxins, which are also polyketides.

Strains were grown, harvested, and DNA extracted according to the protocol of Cenis (1992). The PCR mixture consisted of $200 \mu \mathrm{M}$ of dNTPs (Pharmacia, Herts), 1.25 units of Tth polymerase, Tth buffer (both from HT Biotechnology, Cambridge, UK), $0.8 \mu \mathrm{M}$ of primer IDH1, and IDH2, and template DNA. The IDH gene was amplified at $94^{\circ} \mathrm{C}$ for $1 \mathrm{~min}, 52^{\circ}$ for $1 \mathrm{~min}$, $72^{\circ}$ for 1 min for 30 cycles with a Hybaid, Omn-E thermal cycler. The initial denaturing step was $94^{\circ}$ for 3 min and the programme was completed with an extension step of $72^{\circ}$ for $5 \mathrm{~min}$. The primers (GIBO BRL, Paisley) were designed to amplify 600 base pairs of the IDH gene; IDH1 sequence: 5'-CAATGTGTCGTACT GTGCCC-3', and IDH2 sequence: 5'-ACCTTCAG TCGCTGTTCCTC-3'. The PCR products were separated by electrophoresis on $1.5 \%$ agarose gels (SeaKem

AQ1 LE, FMC Bioproducts, $\boldsymbol{\square})$ in Tris-acetate-EDTA buffer at a constant voltage $5 \mathrm{~V} \mathrm{~cm}^{-1}$. The gels were stained with ethidium bromide and viewed under UV light. The reaction mixtures were diluted with buffer for analyses. Possession of the gene fragment was determined visually as 'band at $600 \mathrm{bp}$ present/absent' (Paterson et al. 2003). Each sample was analysed the number of times indicated by the number of ' + or - ' in Table 2 (i.e. +++ means 3 positive analyses, etc.). Freeze dried cultures (Table 1) were also analysed directly by this method.

\section{RESULTS}

The gene fragment could not be detected in PCRs set up using DNA extracted from freeze-dried cultures. The results of the analysis of grown strains are presented in Table 2. The dilutions are combined into four
Table 1. The isolates examined in this study. The contents of freeze dried ampoules of these strains were analysed for the IDH gene.

\begin{tabular}{|c|c|c|c|}
\hline Fungus & $\begin{array}{l}\text { IMI/Other } \\
\text { accession no. }\end{array}$ & Status & $\begin{array}{l}\text { Isolation } \\
\text { information }^{\mathrm{a}}\end{array}$ \\
\hline Aspergillus terreus & 016043 & & \\
\hline \multirow[t]{4}{*}{ A. clavatus } & 135817 & & \\
\hline & 015949 & $\begin{array}{l}\text { Westerdijk, } \\
1909\end{array}$ & $\mathrm{~T}, \mathrm{AF} 400607^{\mathrm{b}}$ \\
\hline & 358435 & $\begin{array}{l}\text { toxic feed } \\
\text { pellets }\end{array}$ & \\
\hline & 232883 & & \\
\hline A. flavus & 380661 & & \\
\hline \multirow[t]{2}{*}{ A. giganteus } & 343711 & soil, Panama & \\
\hline & 016154 & & \\
\hline \multirow[t]{2}{*}{ Byssochlamys fulva } & 040021 & $\begin{array}{l}\text { bottled fruit, } \\
\text { UK }\end{array}$ & $\mathrm{T}$ \\
\hline & 058422 & soil, UK & A \\
\hline B. nivea & 361545 & & \\
\hline \multirow[t]{2}{*}{ Paecilomyes variotti } & 204127 & & \\
\hline & 321342 & & \\
\hline $\begin{array}{l}\text { Penicillium glandicola } \\
\text { var. glandicola }\end{array}$ & 321513 & soil, USA & \\
\hline $\begin{array}{l}\text { P. glandicola } \\
\text { var. glaucovenetum }\end{array}$ & 321511 & & \\
\hline P. expansum & 028619 & & \\
\hline P. griseofulvum & 075832ii & & $\mathrm{N}$ \\
\hline $\begin{array}{l}\text { P. griseofulvum var. } \\
\text { dipodomyicola }\end{array}$ & 296935 & & $\mathrm{H}$ \\
\hline \multirow[t]{2}{*}{ P. melinii } & 040216 & $\begin{array}{l}\text { forest soil, } \\
\text { USA }\end{array}$ & $\mathrm{T}$ \\
\hline & 304279 & $\begin{array}{l}\text { barley field } \\
\text { soil, Denmark }\end{array}$ & \\
\hline P. selandiae & 304284 & $\begin{array}{l}\text { beach sand, } \\
\text { Denmark }\end{array}$ & \\
\hline
\end{tabular}

${ }^{\text {a }} \mathrm{T}$, ex-type strain; A, named by the author of the species but not ex-type; H, holotype; N, neotype.

* GenBank accession no.

groups for clarity. Positive results only were presented for the combined groups which contained positive and negative data (i.e. -+ was presented as + ). However, each dilution is represented in Fig. 2. Numerous fungi possessed the gene. Positive results were seen in Aspergillus terreus (IMI 135817) and Byssochlamys fulva (IMI 058422). The controls were negative. The results were usually consistent for the gene fragment detection with concentration (Fig. 2). A positive result was not obtained at higher concentrations for $A$. giganteus (IMI 016154), A. terreus (IMI 135817), B. nivea (IMI 058423; 361545), Pecilomyces variotii (204127), Penicillium expansum (IMI 380662), $P$. janczewskii (IMI 381951), P. mellini (IMI 040216), $P$. selandiae (IMI 304284), and P. spinulosum (IMI 380642). The percentages of negative results at each dilution for these strains are provided in Fig. 2. All strains were negative at the dilution of 10 , which decreased to $0 \%$ at $\times 200$. Negative results were checked for at $\times 800$ and 1000 . The equivalent data for $P$. brevicompactum indicated that dilution did not indicate a trend, remaining at an average of approximately $70 \%$ negative results. Similarly for the remainder of the strains where a positive result was observed 
Table 2. IDH gene at various dilutions.

Dilutions $^{\mathrm{a}}$

\begin{tabular}{|c|c|c|c|c|}
\hline \multirow{2}{*}{ Fungus } & & & & \\
\hline & A & B & $\mathrm{C}$ & $\mathrm{D}$ \\
\hline \multicolumn{5}{|l|}{ Aspergillus } \\
\hline \multicolumn{5}{|l|}{ Subgen. Aspergillus } \\
\hline \multicolumn{5}{|l|}{ Sect. Flavi } \\
\hline A. flavus 380661 & $--^{\mathrm{b}}$ & --- & & - \\
\hline \multicolumn{5}{|l|}{ Sect. Terrei } \\
\hline A. terreus 135817 & - & - & + & + \\
\hline 016043 & + & - & -- & -- \\
\hline \multicolumn{5}{|l|}{ Subgen. Fumigati } \\
\hline \multicolumn{5}{|l|}{ Sect. Clavati } \\
\hline A. clavatus $015949 \mathrm{v}$ & + & ++ & +++++ & ++ \\
\hline 358435 & + & ++ & +++ & ++ \\
\hline 232883 & + & ++ & ++ & ++ \\
\hline A. giganteus 343711 & + & ++ & ++++ & ++ \\
\hline 016154 & - & + & + & + \\
\hline Byssochlamys fulva 040021 & - & - & - & - \\
\hline 058422 & + & - & -- & -- \\
\hline B. nivea 361545 & - & - & ++ & - \\
\hline 058423 & - & + & + & + \\
\hline Paecilomyces illacinus 380949 & & - & & - \\
\hline P. varioti 204127 & - & + & ++ & - \\
\hline 321342 & - & -- & ---- & - \\
\hline \multicolumn{5}{|l|}{ Penicillium } \\
\hline \multicolumn{5}{|l|}{ Subgen Aspergilloides } \\
\hline P. glabrum 380331 & - & - & & \\
\hline P. spinulosum 380642 & - & + & + & \\
\hline \multicolumn{5}{|l|}{ Subgen. Biverticillium } \\
\hline P. pinophilum 380659 & -- & --- & & - \\
\hline P. purpurogenum 380952 & -- & -- & & \\
\hline 380948 & - & - & & \\
\hline \multicolumn{5}{|l|}{ Subgen. Furcatum } \\
\hline P. canescens 380320 & - & -- & & - \\
\hline P. citrinum 380323, 380961 & & - & & - \\
\hline 380343 & - & -- & & - \\
\hline 380969,380342 & - & - & & \\
\hline P. corylophilum 380322 & & + & & - \\
\hline \multicolumn{5}{|l|}{ P. janczewskii 381948 , } \\
\hline 380968 & - & - & & \\
\hline 380633 & - & -- & - & \\
\hline 380962,380957 & & - & & - \\
\hline 381951 & - & + & & \\
\hline P. melinii $040216 \mathrm{ii}$ & - & -- & ++ & -- \\
\hline 304279 & + & ++ & +++ & + \\
\hline P. paxilli 380639 & -- & --- & & - \\
\hline 381272 & & - & & - \\
\hline P. raistrickii 380966 & & - & & - \\
\hline P. selandiae 304284 & - & -- & --- & ++ \\
\hline \multicolumn{5}{|l|}{ P. simplicissimum } \\
\hline 380333 & + & + & & \\
\hline 380971,380972 & - & - & & \\
\hline Subgen. Penicillium & & & & \\
\hline Sect. Chrysogena & & & & \\
\hline P. chrysogenum 380958 & & & & \\
\hline 380332 & _- & - & & \\
\hline Sect. Corymbifera & & & & \\
\hline P. hirsutum 381967 , & & & & \\
\hline 382063,382064 & + & + & & \\
\hline Sect. Expansa & & & & \\
\hline P. expansum & & & & \\
\hline 299046,232297 & & & ++ & \\
\hline $380324,380326,380327$ & & & & \\
\hline $380325,380344,380377$ & & & & \\
\hline $380336,380335,380959$ & & & & \\
\hline $380963,380964,380965$ & & & & \\
\hline $\begin{array}{l}380967,381269,381270, \\
381271,381273,381374\end{array}$ & & + & & + \\
\hline
\end{tabular}


Table 2. (Cont.)

\begin{tabular}{|c|c|c|c|c|}
\hline \multirow[b]{2}{*}{ Fungus } & \multicolumn{4}{|c|}{ Dilutions $^{\mathrm{a}}$} \\
\hline & A & $\mathrm{B}$ & $\mathrm{C}$ & $\mathrm{D}$ \\
\hline \multicolumn{5}{|l|}{$380345,381952,381265$} \\
\hline $380970,381268,380960$ & + & + & & \\
\hline 028619 & + & +++ & ++ & ++ \\
\hline 380654 & + & --- & - & - \\
\hline 380350 & + & - & & \\
\hline 380665 & + & +++ & & - \\
\hline 380662 & - & + & + & - \\
\hline 380653,380657 & & + & + & - \\
\hline 380636 & & --- & - & -- \\
\hline 381266 & - & - & & \\
\hline \multicolumn{5}{|l|}{ Sect. Gladiolii } \\
\hline Penicillium glandicola var. glandicola 321513 & + & + & ---- & -- \\
\hline P. glandicola var. glaucovenetum 321511 & + & ++ & +++ & ++ \\
\hline \multicolumn{5}{|l|}{ Sect. Olsonii } \\
\hline P. brevicompactum 380656 & & +++ & + & ++ \\
\hline 380321 & & + & & + \\
\hline \multicolumn{5}{|l|}{$380330,380346,381970$} \\
\hline 380347,380348 & + & + & & \\
\hline 380341 & + & ++ & & + \\
\hline 380334 & + & - & & \\
\hline $381974,381990,380944$ & - & - & & \\
\hline 380349 & -- & -- & & \\
\hline 380352 & -- & --- & & - \\
\hline 380353 & -- & --- & - & \\
\hline 380643,380634 & - & -- & - & \\
\hline 380648,380645 & & -- & - & - \\
\hline 381267 & & - & & - \\
\hline 380329 & - & -- & & - \\
\hline \multicolumn{5}{|l|}{ Sect. Urticicola } \\
\hline P. griseofulvum $075832 \mathrm{ii}$ & + & ++ & +++++ & ++ \\
\hline P. griseofulvum var. dipodomyicola 296935 & & ++ & +++++ & ++ \\
\hline \multicolumn{5}{|l|}{ Sect. Viridicata } \\
\hline P. aurantiogriseum 265302 & & ++ & & \\
\hline
\end{tabular}

a Dilutions are: A, $\times 10$ and/or 50; B, × 100 and/or 200; C, $\times 400$ and/or 500; and D, $\times 800$ and/or 1000 .

$\mathrm{b}+$, gene detected; - , not detected.

Repeated symbols indicate the number of analyses.

from at least one dilution; the average was approximately $15 \%$.

\section{DISCUSSION}

There were differences in results between the lower and higher dilutions for ten strains which could be attributable to inhibition effects (Fig. 2). These were all negative initially, but changed to all positive at higher dilutions. This may have been due to the removal of inhibiting substances. Finally, they attained a level of negative results similar to those of Penicillium brevicompactum. This is likely to be because of target DNA being diluted out. Patulin and/or other extrolites are probable candidates to have caused inhibition (www. inchem.org). The inhibition was reversible. Further experimentation needs to be undertaken to test the inhibition hypothesis, for example, testing pure patulin and other extrolites on the PCR (Paterson, Venâncio \& Lima 2004). In general, DNA extracts could be analysed to determine the concentrations of secondary metabolites as a quality control measure. The possibility exists

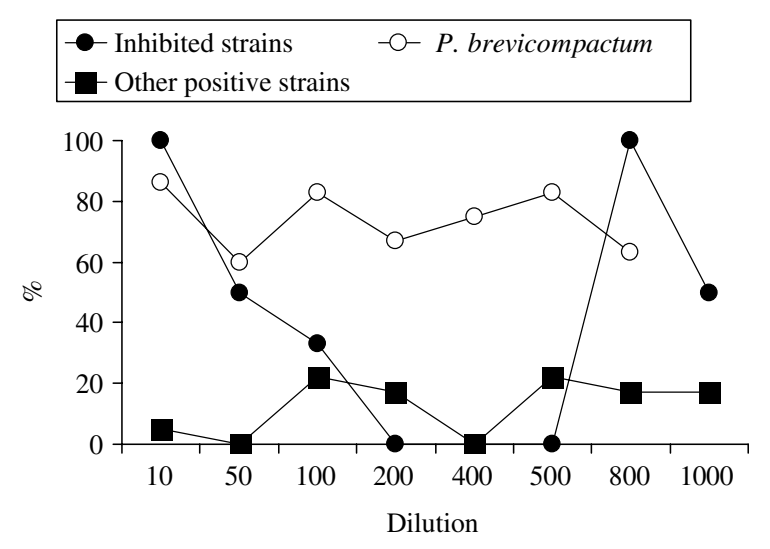

Fig. 2. Negative PCRs at different dilutions.

that the strains recorded as negative are irreversibly inhibited, or that the original DNA has been damaged by extrolites. The potential problem is that the same original DNA may give different results, with implications for nucleic acid analysis in general. The toxicity of patulin is related to its ability to alkylate several 
enzymes, and inhibit translation/transcription by direct effects on DNA, suggesting that it will affect PCRs. It also forms adducts with DNA and is mutagenic.

Any variation in the data presented here, and in Paterson (2003), can be explained by dilution effects. This is the first report of the gene in Byssochlamys fulva and is reassuring as it was the ex-type strain. It confirms the potential of the fungus to produce patulin, which is significant for the food industry.

A good correlation existed between detection and non-detection of the gene, and patulin production and non-detection respectively. All 50 strains which were negative for the IDH gene were negative for patulin detection. $66 \%$ of 50 strains which were positive for the IDH gene were positive for patulin detection. $P$. expansum was consistent, as reported in Paterson et al. (2003). 12 were negative for the IDH gene and also negative for patulin production (Paterson 2003). Six strains were positive for both traits. Three strains were positive for the IDH gene and negative for patulin detection. The resolution of the analytic system (TLC) may have been insufficient in the cases which were IDH positive and patulin detection negative. Varga et al. (2003) reported high consistency, but used potentially more sensitive analytical equipment for patulin detection. Positive patulin detection and negative IDH were not recorded in any of the papers, indicating that DNA samples which were too dilute for analysis are not an issue (and indeed that only a pathway which involved IDH was present).

Direct analyses of freeze dried ampoules, which are analogous to dried herbarium samples (Paterson \& Hawksworth 1985), would be useful in terms of avoiding re-growing the cultures. The negative results obtained in this study might be explained by either insufficient material containing target DNA being present, or inhibition. Attempts should be continued as the capacity would greatly improve the screening of isolates for confirmation of taxonomic identities or examining the effects of preservation methods.

It would be interesting to test other series in subgenus Penicillium for the IDH gene to determine its distribution. The detection of patulin itself in Penicillium subgen. Penicillium was listed as a useful taxonomic attribute by Frisvad et al. (2000). Patulin is a characteristic of the two species in the series Gladiolii $(P$. gladioli and P. sclerotigenum) as it is for P. griseofulvum and $P$. dipodomycicola in the series Urticicola. Patulin detection is also considered as characteristic in six of 8 species in Claviformae. It is noted that patulin detection in Expansa and Roqueforti was not included although they contain patulin producers. In addition, other representatives of the series did not have patulin detection as characteristic.

Table 3 indicates which Penicillium subgenus strains belong to IDH positive or negative groupings. Some strains of P. brevicompactum, and most of P. expansum, have the IDH gene. Traditional forms of identification would not provide this information. I suggest that the
Table 3. Occurrence of the IDH gene in Penicillium subgenus Penicillium.

\begin{tabular}{|c|c|c|}
\hline \multirow[b]{2}{*}{ Fungus } & \multicolumn{2}{|l|}{ IDH } \\
\hline & Positive & Negative \\
\hline \multicolumn{3}{|l|}{ Sect. Chrysogena } \\
\hline P. chrysogenum & 0 & 2 \\
\hline \multicolumn{3}{|l|}{ Sect. Corymbifera } \\
\hline P. hirsutum & 3 & 0 \\
\hline \multicolumn{3}{|l|}{ Sect. Expansa } \\
\hline P. expansum & 33 & 2 \\
\hline \multicolumn{3}{|l|}{ Sect. Gladiolii } \\
\hline P. glandicola var. glandicola & 1 & 0 \\
\hline P. glandicola var. glaucovenetum & 1 & 0 \\
\hline \multicolumn{3}{|l|}{ Sect. Olsonii } \\
\hline P. brevicompactum & 9 & 12 \\
\hline \multicolumn{3}{|l|}{ Sect. Urticicola } \\
\hline P. griseofulvum & 1 & 0 \\
\hline P. griseofulvum var. dipodomyicola & 1 & 0 \\
\hline \multicolumn{3}{|l|}{ Sect. Viridicata } \\
\hline P. aurantiogriseum & 1 & 0 \\
\hline
\end{tabular}

effort expended in identifying to species could instead be re-directed into performing the PCR for the IDH gene. The concept could usefully be extended to other mycotoxins within subgenus Penicillium, although chromatographic methods would be required. The approach would be highly beneficial to mycotoxicologists attempting to find 'weak spots' in the production of food, feed and drink, i.e. 'the commodity systems' (Paterson, Venâncio \& Lima 2004).

In conclusion, the IDH gene, and patulin production, is distributed widely in fungi. Some strains of the same species appear to have: (1) lost, or gained the capability through evolution (Varga et al. 2003); and/or (2) lost the capability through preservation (Paterson 2003). Detection of the IDH gene by PCR is complicated by the inhibition of the PCR reaction by culture components, possibly secondary metabolites. PCR analysis will however assist in clarifying the relationship between secondary metabolism and fungal taxonomy at genomic and secondary metabolomic (Paterson 2004) levels.

\section{ACKNOWLEDGEMENTS}

Some of this work was undertaken as part of UK Food Standards Agency contract no. CO30005. I thank Zofia Kozakiewicz for project fungal identifications. The laboratory work reported here was undertaken at the CABI Bioscience UK Centre, Egham.

\section{REFERENCES}

Bhatnagar, D., Payne, G. A., Cleveland, T. E. \& Robens, J. F. (2004) Mycotoxins: current issues in U.S.A. In Meeting the Mycotoxin Menace (D. Barug, H. P. van Egmond, R. López-Garcia, W. A. Osenbruggen \& A. Visconti, eds): 17-47. Wageningen Academic Press, Wageningen. 
Byrne, B. (2004) Commission regulation (EC) No 455/2004 of 11 March 2004. Amending Regulation (EC) No 466/2001 as regards patulin. Official Journal of the European Union 1.74/11.

Casas Lopez, J. L., Rodriguez Porcel, E. M., Vilches Ferron, M. A., Sanchez Perez, J. A., Fernandez Sevilla, J. M. \& Chisti Y. (2004) Lovastatin inhibits its own synthesis in Aspergillus terreus. Journal of Industrial Microbiology and Biotechnology 31: 48-50.

CAST (2003) Mycotoxins: risks in plant, animal, and human systems. Council for Agricultural Science and Technology, Ames, IA.

Cenis, J. L. (1992) Rapid extraction of fungal DNA for PCR amplification. Nucleic Acid Research 20: 2380.

Fedeshko, R. W. (1992) Polyketide enzymes and genes. 2 vols. PhD thesis, University of Calgary, Calgary.

Frisvad, J. C. \& Thrane, U. (1993) Liquid column chromatography of mycotoxins. In Chromatography of Mycotoxins Techniques and Applications (V. Betina, ed.): 253-372. Journal of Chromatography Library Vol. 54. Elsevier Amsterdam.

Frisvad, J. C., Filtenborg, O., Lund, F. \& Samson, R. A. (2000) The homogeneous species and series in subgenus Penicillium are related to mammal nutrition and excretion. In Integration of Modern Taxonomic Methods for Penicillium and Aspergillus Classification (R. A. Samson \& J. I. Pitt, eds): 265-283. Harwood Academic Publishers, Amsterdam.

Johnston, C. G. \& Aust, S. D. (1994) Detection of Phanerochaete chrysosporium in soil by PCR and restriction enzyme analysis. Applied and Environmental Microbiology 60: 2350-2354.

Laich, L., Fierro, F. \& Martin, J. F. (2002) Production of penicillin by fungi growing on food products: identification of a complete penicillin gene cluster in Penicillium griseofulvum and a truncated cluster in Penicillium verrucosum. Applied and Environmental Microbiology 68: 1211-1219.

Moss, M. O. (1998) Recent studies of mycotoxins. Journal of Applied Microbiology Symposium Supplement 84: 62S-76S.

Nicolaisen, M., Frisvad, J. C. \& Rossen, L. (1997) A Penicillium freii gene that is highly similar to the $\beta$-keto-acyl synthase of polyketide synthase genes from other fungi. Letters in Applied Microbiology 25: 197-201.

Paterson, R. R. M. (2003) The isoepoxydon dehydrogenase gene of the patulin biosynthetic pathway, patulin detection, and the utility of species names in patulin-producing fungi. In Biological Resource Centres and the use of Microbes, European Culture Collections' Organisation XXII (N. Lima \& D. Smith, eds): 259-266. Micoteca da Universidade, Braga.

Paterson, R. R. M. (2004) [Book Review.] Mycological Research 108: 721.

Paterson, R. R. M., Archer, S., Kozakiewicz, Z., Lea, A., Locke, T. \& O'Grady, E. (2000) A gene probe for the patulin metabolic pathway with potential use in novel disease control. Biocontrol Science and Technology 10: 509-512.

Paterson, R. R. M. \& Hawksworth D. L. (1985) Detection of secondary metabolites in dried cultures of Penicillium preserved in herbaria. Transactions of the British Mycological Society 85: 95-100.

Paterson, R. R. M. \& Kemmelmeier, K. (1989) Gradient high performance liquid chromatography using alkylphenone retention indices of insecticidal extracts of Penicillium strains. Journal of Chromatography 483: 153-168.

Paterson, R. R. M., Kozakiewicz, Z., Locke, T., Brayford, D. \& Jones, S. C. B. (2003) Novel use of the isoepoxydon dehydrogenase gene probe of the patulin metabolic pathway and chromatography to test penicillia isolated from apple production systems for the potential to contaminate apple juice with patulin. Food Microbiology 20: 359-364.

Paterson, R. R. M., Ribeiro, A., Machado, P., Venâncio, A. \& Lima, N. (2004) Patulin, a patulin gene and a data base of other mycotoxins from bottled water factory penicillia. Journal of Chromatography: in press.

Paterson, R. R. M., Venâncio, A. \& Lima, N. (2004) Solutions to Penicillium taxonomy crucial to mycotoxin research and health. Research in Microbiology: in press.

Peterson, S. W. (2004) Multilocus DNA sequence analysis shows that Penicillium biourgeianum is a distinct species closely related to $P$. brevicompactum and $P$. olsonii. Mycological Research 108: $434-441$.

Santos, I. M., Abrunhosa, L., Venâncio, A. \& Lima, N. (2002) The effect of culture preservation techniques on patulin and citrinin production by Penicillium expansum Link. Letters in Applied Microbiology 35: 272-275.

Scott, R. E., Jones, A., Lam, K. S. \& Gaucher, G. M. (1986) Manganese and antibiotic biosynthesis. 1. A specific manganese requirement for patulin production in Penicillium urticae. Canadian Journal of Microbiology 32: 259-267.

Varga, J., Rigó, K., Molnár, J., Tóth, B., Szencz, A., Téren, J. \& Kozakiewicz, Z. (2003) Mycotoxin production and evolutionary relationships among species of Aspergillus section Clavati. Antonie van Leewenhoek 83: 191-200.

Wang, H.-J., Gloer, J. B., Wicklow, D. T. \& Dowd, P. F. (1995) Aflavinines and other antiinsectan metabolites from the ascostromata of Eupenicillium crustaceum and related species. Applied and Environmental Microbiology 61: 4429-4435.

Wang, I.-K., Reeves, C. \& Gaucher, G. M. (1991) Isolation and sequencing of a genomic DNA clone containing the 3 'terminus of the 6-methylsalicylic acid polyketide synthetase gene of Penicillium urticae. Canadian Journal of Microbiology 37: 86-95.

Yalpani, N., Altier, D. J., Barbour, E., Cigan, A. L. \& Scelonge, C. J. (2001) Production of 6-methylsalicylic acid by expression of a fungal polyketide synthase activates disease resistance in tobacco. Plant Cell 13: 1401-1410.

Corresponding Editor: M. Ramsdale 